Egon Franck, Christian Opitz*

\title{
The Singularity of the German Doctorate as a Signal for Managerial Talent: \\ Causes, Consequences and Future Developments ${ }^{* *}$
}

The paper focuses on signaling options for managerial talent under different higher education regimes. The educational paths in a sample of top managers of the 100 largest publicly traded companies in the U.S., France and Germany are consistent with our theoretical conjectures. For the singular role of the German doctorate, the traditional chair system in doctoral education and training is essential. The effects of higher education reforms are discussed.

In Germany the doctorate is a powerful signal for managerial talent. Future signaling options are closely tied to German higher education reform.

Key words: Doctoral Education, Signaling, Managerial Talent, German Higher Education, Higher Education Reform

* Professor Dr. Egon Franck, University of ZurichInstitute of Strategy and Business Economics, Plattenstr. 14, 8032 Zurich, Switzerland, phone: ++41 44 6342845, fax: ++41 44 6344348, e-mail: egon.franck@isu.unizh.ch.

Professor Dr. Christian Opitz, Zeppelin UniversityZF-Friedrichshafen Chair for Strategy and Leadership, Am Seemooser Horn 20, 88045 Friedrichshafen, Germany, phone: ++49 75416009 1251, fax: +49 75416009 1299, e-mail: christian.opitz@zeppelin-university.de.

** Article received: September 7, 2006

Revised version accepted after double blind review: April 2, 2007.

management revue, 18(2): 220-241

ISSN (print) 0935-9915, ISSN (internet) 1861-9916, (C) Rainer Hampp Verlag, www.Hampp-Verlag.de 


\section{Introduction}

Comparative international studies of top management careers routinely point to the unparalleled percentage of doctoral degree holders among German top managers (e.g. Hartmann 2000). Moreover, empirical studies devoted to the analysis of career perspectives among German university graduates report superior career opportunities for candidates holding a doctoral degree not only in universities and research institutes but also in public administration, politics and in the private sector. The German doctorate is highly valued among employers in various industries (Enders/Bornmann 2001; Baldauf 1998).

These findings indicate that the traditional German doctoral education was not exclusively directed at the scientific labor market. Unlike the Ph.D. in the U.S. and the doctorates in many other countries, the German doctoral degree has obviously not been perceived by the labor market as a specialized indicator for research abilities in a certain scientific field. In order to serve as an 'accelerator' for a management career in business and public administration, the German doctoral degree must have been rather understood as an indicator for a more general form of human capital. For reasons of simplicity we will speak of 'managerial talent' when we refer to this kind of general human capital, which enhances the productivity of a candidate in many different employments.

The interpretation of the traditional German doctorate as an indicator for managerial talent raises different puzzles: First, which economic mechanisms produce this singular property of the German doctorate as compared to doctoral degrees in other countries? Second, which economic mechanisms substitute for this property of the German doctorate in other countries and third, will this specific property of the German doctorate prevail considering the recent changes and reforms in German higher education?

The general role of indicators for human capital has been extensively studied. Employers cannot assess the productivity of potential employees without cost. With time, employers may learn more about the workers' true productivity and subsequently modify the provided employment conditions. However, in many professional services and for higher job levels in general, the productivity of a worker may never become fully observable because labor output depends on multiple and complex exogenous variables. Consequently, employers frequently face a substantial risk of adverse selection in their employment decisions.

The negative effects of information asymmetries between employees and employers are not only borne by the latter. Employees are equally concerned, since wages and career options reflect average qualities rather than the applicants' individual endowment. Individuals with an above-average talent have strong incentives to reduce information asymmetries and to actively communicate their superior potential. As Arrow (1973) pointed out higher education, among other things, may function as a filter in this context. Certifying that individuals have 'passed' through specific filter devices, educational credentials could serve as signals for certain aspects of human capital that employers may find valuable. 
However, as a consequence of institutional differences between the higher education systems of different countries, filter functionalities may also vary from country to country. Individuals endowed with the abilities and motivation to pursue a top management career, which we will refer to as 'high potentials', may have to follow specific 'model educational paths' defined by the institutional set-up of their national higher education systems in order to signal their managerial talent to potential employers.

From this perspective, untangling the singular role of the doctorate for a top management career in Germany means untangling the importance of different 'model educational paths' for signaling managerial talent in the context of different national higher education systems. Such differences in signaling requirements across countries have not received much attention, whereas the signaling of human capital via educational credentials has been analyzed in detail (Riley 2001). Following the seminal work of Arrow (1973), Spence (1973) and Stiglitz (1975) a large body of empirical research testing the so called 'signaling-' or 'screening-hypothesis' has developed (e.g. Groot/Oosterbeck 1994; Grubb 1993; Cohn/Kiker/Medes de Oliveira 1987). In this literature, it is always assumed - either explicitly or implicitly - that the degree issuing institutions have the right incentives to perform their filtering role well. However, the credibility of degrees is not at all that obvious.

Accordingly, the market for 'filtering services', too, is characterized by substantial information asymmetries. Employers, for example, who intend to overcome information asymmetries in the labor market by using educational credentials as a signal for managerial talent are situated outside the higher education system and should thus have serious difficulties to evaluate whether a certain university performs the selection and education of its students in accordance with a promised level of effort and care. Why should potential employers trust the services of a particular university and associate her credentials with human capital of a certain quality if filtering causes costs? Or to put it differently, which mechanisms are successful in preventing cheating behavior by the degree issuing institution? Consequently, in order to be meaningful on the labor market, educational credentials have to be validated somehow.

The analysis presented in our paper shows that this problem of 'signal validation', which precedes the problem of signaling talent, is handled differently in different national higher education systems. Specific national 'model educational paths' simply reflect this validation diversity. The unparalleled percentage of doctoral degree holders among German top managers is a consequence of the fact that doctoral education is part of the 'model educational path' of high potentials in Germany, but not in other countries. We proceed through several steps in order to derive our results.

In section 2, starting from Arrow's hypothesis that higher education is a 'filter' for human capital, we discuss two distinctive filter-designs that fulfill the requirement of signal validation. We use the term 'competitive validation model' for a higher education system in which market forces ensure the credibility of filtering services, whereas 'bureaucratic validation model' refers to a system in which government control performs this function. As ideal types, these two arrangements provide a framework that can be used to classify the higher education systems of the U.S., France and Germany. We infer 'model educational paths' for candidates wishing to signal mana- 
gerial talent in the domestic labor markets of these three countries (section 3). This analysis explains why the doctorate is an attractive signal for German high potentials and why U.S. and French high potentials are likely to follow different routes. In section 4, we confront the inferred 'model educational paths' with empirical information on top management careers in those three countries. The results are consistent with our theoretical conjectures. In section 5, we consider recent reforms in German higher education, which have the potential to change the signaling content of the German doctorate and may provide German high potentials with alternative instruments to signal their talent in the future.

\section{Ideal filter designs in higher education}

\subsection{The competitive validation model: Performance-related rewards, commitment and the evolution of hierarchical higher education markets}

What we call the 'competitive validation model' is characterized by a high degree of competition between schools and a low degree of state regulation. Institutions of higher education are autonomous and substantially free in most aspects of their decisions. They plan, realize and modify their curricula, select their student bodies and have far-reaching financial autonomy with all its implications. They are free to accumulate wealth through various methods of fund raising. This implies, of course, that they can also charge tuition fees that are paid for by their customers, i.e. their students. The amounts charged as well as the salaries paid to their scientific personnel are market prices, in the sense that they are not restricted by state regulation. Universities compete for scarce input-factors like talented students and professors as well as for research contracts that may be both privately and publicly funded.

Because universities individually take in the proceeds from donations, research contracts, tuition fees and other sources, this competitive setting entails the potential for performance-related rewards (Franck/Opitz 2006). Schools that continue to deliver high quality in research and teaching gain reputation which in turn spurs the demand for their services and ultimately augments their disposable income.

However, if the markets are to reward or punish universities based on the quality of the services provided by them, they must be able to discern the quality of these services without undue cost. The competitive validation model presupposes that institutions of higher education succeed in signaling their own quality into the markets they serve. In the market for filtering services, which is the focus of interest of our analysis, students earn degrees because they enable them to signal a certain quality of human capital to potential employers. But why should employers trust the services of a certain university and associate the issued credentials with human capital of a certain promised quality? The answer proposed here is: Because the universities are able to design mechanisms that credibly reveal information about the quality of their filtering services. In other words: In the competitive model the 'meta-signaling' of universities in the market for filtering services validates their degrees as credible signals in the labor market.

Now, which is the potential starting point for this meta-signaling of universities? Technological peculiarities of university production are at the core of the signaling mechanism. The production process of higher education is determined to a high de- 
gree by the input it receives - that is, by human capital. Talented and motivated students and professors play a crucial role in teaching and research. Strong peer effects increase the importance of human capital (Astin 1993; Pascarella/Terenzini 2005). In a group of talented and motivated students (and professors) nobody wants to fall behind. Everyone benefits from the motivation and abilities of his peers. Rothschild and White (1995) speak of a 'customer-based production technology' to stress the dominant role of the students (i.e. the customers) for the output produced by universities. Universities devoting more care and skill to securing the high quality of their students (and academics) will also produce better results, especially in the face of strong peer effects. Under these 'technological' conditions universities can signal high quality output if the markets somehow perceive that only outstanding applicants (students and academics) are chosen and promoted at all stages of production. Consequently, input selectivity is a key to output quality in the educational services industry.

However, at this point we must ask how a high degree of input selectivity can be communicated into the markets. Low admission quotas for their programs, for instance, are self-evident since a university denying access to many applicants automatically produces the experience of rejection within the segment of potential applicants. Presumably, however, the information of admission quotas does not reach far enough.

Strictly speaking, the lowest admission rate only indicates a favorable access position of a university within the corresponding market segment of potential students. A university which can afford to reject the most applicants in a certain market segment of potential students has some priority over its rivals when checking the whole 'student supply'. Yet, the crucial question remains unanswered: Why should a favorable position in this pecking order in fact be used to select the most talented students? Or to put it differently: How can it be assured that universities using their superior access position to the detriment of their customers (other students and employers) - e.g. by not selecting according to talent and motivation - harm their own prospects?

Another peculiarity of higher education turns out to be a promising starting point for the design of mechanisms suited to overcome this difficulty. Students cannot fully evaluate the quality of the education received before and even immediately after consumption. However, based on various social comparisons with colleagues, friends, peers or relatives, graduates will begin to gain a more precise understanding of the true value of their education and the degree they obtained in the course of their lives and careers.

Universities in a competitive setting may use this slow quality revelation feature of higher education to build up a commitment mechanism. By offering their graduates the possibility to pay for their education at times when they have better learned about its true value and according to their level of satisfaction, universities can make themselves deliberately dependent on the future evaluation of their graduates.

At first sight, this approach seems to be contradictory to the payment of up-front tuition fees. In a competitive setting, however, tuition fees generally cover only a fraction of the total cost of education. Universities tap a variety of different revenue sources. The ratio between tuition fees and total cost of education should become smaller, the more renowned the schools are. Only students of vocational schools at 
the lower end of the reputational spectrum should fully pay for the expenses of their own education at the time of consumption (i.e. when being enrolled). Even if students at top schools pay higher fees in absolute terms, they should receive an education whose costs exceed the fees considerably. The commitment mechanism described above requires that the committing school gives an 'advance' to its students. The greater this advance becomes, the more the school is dependent on future income generated by its graduates.

In a certain sense the university makes itself a 'financial hostage', which its students may release after the quality of its previously rendered services is revealed. This usually happens at a later point in the students' careers. Therefore, advances of this kind are an integral part of the mechanism that validates signals like the discussed input selectivity. The university that takes the risk of such an initial loss is bound to perform its job in a superior way in order to produce the successful graduates that enable it to recuperate from these initial losses later in time.

The mode of operation of the described deferred payment mechanism is multifold. Alumni do not necessarily have to make contributions from their private income to pay back their alma mater. Above-average success of graduates in a competitive setting positively acts upon universities in many ways. Ceteris paribus, successful graduates are able to give more financial and other support to their alma mater not only as private persons but also as officers in firms or administrators in government and other state authorities. Moreover, they have a higher influence on third parties and institutions that may sponsor the education system. The willingness of sponsors to donate money to schools is augmented by the success of their graduates, firstly because success captures the attention of donors, and secondly because donors prefer institutions that prove to 'make something' out of their money (Weisbrod/Dominguez 1986). In addition, above-average success of graduates captures the attention of firms, which may spur the demand for research and consulting services offered by the university and at the same time facilitate the job-hunting process of current graduates considerably. Higher starting salaries for graduates consequently allow for higher tuition fees and yet higher educational costs, and so forth.

The whole signaling process is subject to significant path-dependencies, as can be shown in the context of input-selectivity. As soon as some university gains the reputation to produce graduates with above-average human capital, a positive feedback loop is triggered. Highly talented and motivated students recognize that they can only communicate their superior human capital to potential employers if they also graduate from this school. To be rated as second category in the labor market is particularly unattractive for those students talented enough to make it through a top school. Due to a larger pool of highly talented and motivated applicants, top schools can perform a more rigid selection and thereby further improve their input quality. Lower ratios of applicants to admissions in turn, provide a signal for the superior quality of their output. The reputation of an institution rises, and its opportunity for selectivity is further increased. Unsatisfied student demand and a school's reputation are correlated or to use Frank's and Cook's (1995: 36) expression: 'success breads success'.

In a competitive environment path-dependencies lead to a differentiated and rather stable hierarchy of universities, which Winston (1999: 13) refers to as a 'hierar- 
chical higher education market'. Only a few universities may achieve the reputation of a top school, independent of how high the average quality and total number of institutions might be. Just like in every tournament, the top places are limited by definition.

In a hierarchical higher education market, every school performs a distinct signaling role by attracting only a defined segment of the student population and serving a specific segment of the labor market. Students deliberately select themselves into those schools that offer the best fit between the educational level and their abilities as well as further career plans. On the other hand, employers prefer hiring graduates from those schools that meet their specific human capital demand best.

\subsection{The bureaucratic validation model: Monitoring of predefined quality differences between schools by the state}

Higher education systems employing what can be termed a 'bureaucratic validation model' are characterized by a high degree of state regulation and, in their extreme form, the complete absence of competition between schools. Universities have no or very little financial autonomy and heavily dependent on the state as the main financier of higher education. Moreover, this means that the utilization of funds within universities is limited by a pre-specified official allocation system based on yearly budgets that allows only little discretion at the university level. The accumulation of wealth is not an option in a financial system, where yearly budgets must be spent in order to preserve the chance of renewal for the next period. Moreover, the state regulates the allocation of students and academics to schools by defining application criteria and selection procedures, which are obligatory throughout the system. Tuition fees, if they exist at all, are not market prices but rather taxes charged by the state according to a uniform scheme.

Under this regime there is no possibility for the universities - and no necessity either - to make themselves dependent on the future success of their graduates. The well-being and sustainability of a school is at the discretion of the state and not - as in the competitive model - tied to the valuation of the quality of its services by market forces.

Consequently, quality differences between schools or types of schools need to be predefined by the state as well. The state can do so by setting different standards for curricula, by prescribing different admission and promotion procedures for students and academics and by redistributing financial and other complementary resources in accordance to the desired quality segmentation. In the bureaucratic model school reputation is determined by rationing inputs. The structure of bureaucratic higher education systems therefore may be uniform or it may deliberately assign schools to different quality standards. It may even provide a segment of elite-education. This, of course, presupposes the allocation of outstanding financial and complementary resources to a small number of schools that is accompanied by a deliberate redirection of superior student and academic talent to these places.

Commitment mechanisms of the kind employed in the competitive model (i.e. at the university level) are out of question in this bureaucratic setting. Only the state can prevent the erosion of the predefined quality standards over time by closely monitoring the compliance of the institutions of higher education with the regulations. These 
monitoring activities of the state, however, cannot be completely observed and evaluated by outsiders. Again, a problem of validation arises. Why should potential students and employers trust the monitoring activities of the state and associate certain academic degrees with a specific level of educational quality or human capital, respectively?

Since commitment mechanisms are curbed at the university level in this bureaucratic regime, it is again up to the state to back up the credibility of the performed monitoring activities. The prominent instrument in this context is the crafting of a consistent public employment policy. By defining entry standards and qualification requirements for the whole range of careers within the public administration, the state validates whatever concept of higher education the government decided to implement. To be effective, this validation strategy presupposes a sufficient number of positions in the public sector to be filled at any point in time. Obviously, the strategy is easier to implement in rather centralized economic systems with a pronounced government sector. The more differentiated the requirements for human capital in the administration are, the more quality segments in higher education can be successfully stabilized by the employment policy of the state.

The descriptions given so far refer to two prototypical validation models. In practice, the boundaries between the described ideal types may be more blurred. Intermediate forms like, for example, competitive systems, in which public and private institutions coexist and both receive state subsidies, and bureaucratic systems, in which some areas remain unregulated, may emerge.

\section{Signal validation and 'model educational paths' for high potentials in the U.S., France and Germany}

Higher education systems characterized by specific validation mechanisms for educational credentials should have a predictable effect on the educational choices of individuals intending to signal their talent. High potentials have particularly strong incentives to signal their talent, since they would incur the highest losses if they were treated according to average expectations by potential employers. Consequently, the propensity to 'use' the higher education system of their country as a signaling and certification system for talent in the Arrowian sense should be more accentuated among the members of this group. High potentials should follow specific 'model educational paths' that serve their interest to accelerate the revelation of their human capital in the best possible way.

In the following section we infer this model educational path by analyzing the specific structure and the employed validation mechanisms in the higher education systems of the U.S., France and Germany. In the next step, these model educational paths will be confronted with empirical evidence from top management careers in the respective countries. We assume that these top managers originated from the group of highly talented individuals. ${ }^{1}$ Did and to what extent did they follow the model educational path inferred for their country?

1 This assumption is based on another assumption, which in its shortest form states that 'labor markets may work slowly but they work'. Careers do not start at the top of organi- 


\subsection{Hierarchical higher education market in the U.S.}

Higher education in the U.S. displays many distinctive features of the competitive model described above (Geiger 2002). The industry consists of public and private institutions that compete for students, faculty, research money, donors and sponsors. In addition to the subsidies given to them by the state, these institutions actively raise funds from sources like tuition fees, donations, alumni-givings, research grants, sponsoring and the like. Together with the income earned from the accumulated significant endowments these non-state sources in general make up for a significant fraction of total income. Competition has lead to a broad differentiation and a rather stable hierarchy of schools. The more famous the school is, the larger becomes the 'advance' given to the students (in the sense of education costs not covered by up-front tuition). Students at top schools pay higher fees, but they receive an education that costs, in some cases, five times as much as the associated fees (Winston 1999).

Quality indicators are routinely applied in ratings of U.S. colleges and universities. Selectivity regarding the human capital input is attested by low admission quotas and high scores of accepted applicants in the standardized tests such as SAT and GMAT. Other popular indicators include starting salaries and placement statistics of graduates, as well as the university's endowment and alumni-givings. All these indicators fit into the described commitment- and signaling-logic of the competitive model.

In a country with institutions of higher education that are hierarchically segmented into different reputational layers, educational choices have clear signaling consequences. Highly talented and motivated students recognize that they can best communicate their superior human capital to potential employers if they attend one of the highly selective schools. Since selectivity is a relative criterion, the number of elite schools suited for signaling purposes is limited by definition.

The obvious advice for high potentials therefore is to 'throw' themselves into the most selective filter they can pass, or in other words: these individuals should try to enroll at one of the few universities which are ranked as top schools. These institutions have most effectively committed themselves to maximize graduate success. Their positive evaluation and documentation of the applicants' abilities and talent over time will convince best in the labor market.

\subsection{Bureaucracy with elite-education at the Grandes Écoles in France}

Higher education in France displays a number of features that can be associated with the bureaucratic model. The industry is dominated by public schools, which are heavily subsidized and operate within a framework defined by a broad array of regulative procedures (Musselin 1992; Chevaillier 1998, 2001). Ultimately, admission and promotion procedures, education policies and the allocation of resources within the French system of higher education are in control of the state.

zations and promotion through the ranks is based on continuous evaluation. It takes time to reveal human capital, which is the reason why high potentials try to accelerate the revelation process through signals. However, 'low potentials' do not make it to the top since the absence of managerial talent cannot be hidden through all the evaluation rounds necessary to be promoted again and again. 
The hierarchy of the French higher education system consists of several layers with a small group of prestigious Grandes Écoles forming an elite-segment at the top. Elite education has a long tradition in France. At the end of the $18^{\text {th }}$ century, the first Grandes Écoles were founded with the mission to educate candidates for top positions in government and administration, a practice that continues until today. By systematically recruiting graduates of the Grandes Écoles for public service, the state validates the degrees issued by these schools. In order to ensure that the administration is in constant demand for graduates from the respective Grandes Écoles, a systematic migration of senior state officers into the top management of large and more or less statecontrolled firms has to be organized. This practice is called 'pantouflage' in France (Vaughan 1981). It serves the administration since it facilitates the continuous validation of elite education. At the same time the state also legitimizes the degrees of the other graduates of the Grandes Écoles, who take the direct route towards the private sector.

How should high potentials heading towards a top management career behave in this setting? Obviously, the model educational path for top managers in France should lead them through the selective filters of the state-defined elite schools and include a period of service in the state administration.

\subsection{Bureaucracy without a predefined elite-segment in Germany and the doc- torate as a signal for managerial talent}

Similar to the French system, German higher education displays many features of the bureaucratic model. Apart from a few and rather new private schools, which are mostly devoted to business studies and serve only an insignificant fraction of the total student population, institutions are state-financed and state-owned. Despite a number of recent reforms, institutions of higher education are subject to rigid state regulation. Regulatory procedures not only cover public schools but even those in the emerging private sector, albeit to a smaller extent (Huisman 2003).

In contrast to France, however, the education politics of all German governments after the Second World War have not been conducive to the creation of an elitesegment among the institutions of higher education. Instead, governmental policy was aimed at securing a rather homogenous academic landscape. The only hierarchical element within German higher education is formed by the distinction between 'Universitäten' and 'Fachbochschulen'. Fachbochschulen offer a shorter and more practice-related curriculum and are not allowed to award doctoral degrees so far. Quality differences between these two segments are stabilized by different career-paths and salaries in government service.

Until recently public Universitäten apart from some insignificant exceptions had to enroll all applicants with an 'Abitur' (the German high school diploma) allocated to them by a centralized state agency. This agency distributed students to schools along several criteria including Abitur-grades and proximity to home, with the consequence that these institutions had no or very little control over their student input. Nowadays, German universities are allowed to select their applicants more independently by defining specific selection criteria. It is highly unlikely that this single factor taken by itself makes a big difference. Why should universities spend time, money, and energy 
on input control, if the future success of graduates does not significantly and in due time affect the university's resources?

Within the two segments of public Universitäten and Fachbochschulen state regulation clearly aims at securing a rather egalitarian structure. While it is true that certain establishments are somewhat more recognized than others (at least for specific fields of study), the hierarchy between schools is not as explicit or as transparent as in the U.S. or in France. ${ }^{2}$ As a consequence, German students cannot really choose between filtering devices of different strength. This egalitarian set-up seems to be well understood in the business world. In a recent survey among Germany's largest 250 employers the importance of the school a graduate had completed ranked ninth out of ten categories influencing the employment decision. It followed behind criteria like internships with a company, language skills, final grade, stay in a foreign country and length of study. The only criterion of lesser importance in this study was the applicant's age (Leffers 2003). Without a valid elite-segment in higher education, which would enable the production of a more precise signal of their qualities, German high potentials have incentives to invest in additional signal-providing activities in order to communicate their outstanding talent.

A prominent candidate among these additional signals is the German doctoral degree. In our perception the validity of the doctoral degree as a signal for managerial talent is directly linked to one of the few competitive elements in German higher education: The incentives of German university-professors to manage their individual reputation. We do not intend to say that U.S.-American or French professors lack these incentives. Instead, we want to stress that German professors employed at Universitäten still have them despite an otherwise egalitarian regulatory environment.

Professors with a good reputation will be more successful when applying for vacant positions at other schools. The official salary scale leaves room for several increases, which may be offered to professors along with other resources by the respective state ministry as incentive to change or stay (Schimank 2001). At the same time, the job market entails the option to choose one's location. This free choice of location becomes increasingly relevant in the face of peer effects and secondary occupations outside the university. Professors thus capitalize their individual reputation by working out new contracts with the state as well as with other clients who pay for their services privately (e.g. in the case of expert reports, consulting or instruction). Of course, reputation can also be satisfactory in itself without being transformed into pecuniary rewards in secondary markets.

In order to understand how the incentives of German professors to manage their individual reputation contribute to the validation of the doctoral degree as a signal for managerial talent, we need to look at the relation between professors and doctoral candidates in the traditional chair-based organization of German Universitäten. Within this organization, doctoral education and training takes place in the form of a 'masterapprenticeship-model' which implies a rather close and personal relationship between a doctoral candidate and his or her supervisor, the chair holder (Baldauf 1998; Kehm

2 Or as Enders and Teichler (1996: 439) state: 'German universities are assumed to be fairly homogeneous, as far as the quality of teaching and research is concerned.' 
2005). Since the candidates are not integrated in a formal study program, qualification is non systematic and highly depends on the supervisors engagement. Although there are different patterns of support, the large majority of doctoral candidates work as staff member (wissenschaftliche Mitarbeiter) with temporary (full-time or part-time) contracts at university chairs. ${ }^{3}$ The status of personal assistant to the professor constitutes a rather extreme degree of personal dependence, since professors are not only superiors, deciding over contract renewals, but also academic teachers supervising and reviewing the doctoral thesis. In addition, German professors have substantial degrees of freedom when deciding how to employ their scientific personnel. For chair assistants only their obligation in teaching is contractually fixed. However, in addition to helping professors with lectures and exercises, assistants routinely support their principals with research assistance and perform various other activities. In the German chair-based organization professors have far-reaching and legitimized access to additional work power. Therefore, it is not completely exaggerated to portray the relation between professors and doctoral students as a temporary 'exploitation license'. Professors maximize the benefits of this license if they employ the most talented candidates only. This is the case, regardless if professors are interested in enhancing their own reputation within the research community or rather within the local business world. Research-oriented professors have a strong self-interest to invest in the research skills of their assistants, while more practice-oriented professors have incentives to develop their assistant's management skills which are valuable for leadership positions outside academia. In the traditional chair-based system of doctoral education and training assistants are 'valuable', independently of the professors' personal orientation and goals.

For firms that recruit graduates holding a doctoral degree for a future management career a sound scientific education seems to play a minor role anyway. What counts, however, is the selection of the candidate by the professor. Employers anticipate that professors will select carefully and make use of the information advantage stemming from their position as insiders, since they can enhance their own utility level through the 'exploitation license'. In fact, when selecting candidates and appointing his or her own staff German professors for the first time directly benefit from using their superior information about the students they teach. This holds, as mentioned already, for professors who are oriented towards research, as well as for those more interested in consulting or other business related activities. Talented and ambitious candidates maximize the value of the 'exploitation license' in both cases.

What does all of this mean for the expected model educational path of high potentials in Germany? As students they should have preferred Universitäten over Fach-

3 Other funding for doctoral work includes junior positions at research organizations outside of universities, stipends granted by various institutions (the Länder, the German Research Foundation (DFG), political parties, churches and trade unions) and self-support. In 1995 the distribution of doctoral candidates by category of funding was estimated as follows: junior staff at universities $(70 \%)$, junior staff at research institutes $(7 \%)$, grants (14\%), self-financed (10\%) (Baldauf 1998: 169). Berning and Falk (2006) report the following figures for Bavaria in 2002/2003: Junior staff at universities and research institutes $(72 \%)$, grants $(12 \%)$, self-financed $(16 \%)$. 
hochschulen, but at the university level, the identity and thus the reputation of the school should have been less important. The doctoral degree, on the other hand, should be widely spread among the group of German high potentials due to its significant signaling function.

\section{Educational paths of top managers in the U.S., France and Germany}

To examine the educational paths of top managers in the U.S., France and Germany we have drawn on systematic information compiled on Chief Executive Officers (CEO), Présidents Dirécteurs Généreaux (PDG) and Vorstandsvorsitzende (VV) of the one hundred largest companies in the three countries under consideration. ${ }^{4}$ The selection of the companies was conducted on the basis of market capitalization data from April 24th, 2001. Educational and career information has been obtained from various sources, including company homepages and different editions of 'Marquis's who's who' and 'Who's who in European business'. In some cases we were able to collect missing information by contacting the respective firms directly.

We expect that the incentives to signal ability via educational credentials vary systematically with the status of a top manager. We therefore omitted inheritors, founders as well as a group that may be termed as 'foreign governors' from our sample. Inheritors get to the top of a firm due to their property rights, and not because they were able to convince potential employers of their outstanding qualities as managers. Inheritors should have a reduced need to signal ability to outside-owners or their agents. Another group that should be less focused on signaling managerial abilities to potential employers are founders heading their own firms. Finally, it is common practice that the top managers of subsidiaries abroad are appointed by the headquarters of the firm. These top managers are foreign governors in their country of operation. We do not intend to say that foreign governors do not have to signal their above-average human capital. Of course, they need to, but rather on their domestic labor markets. Therefore, they cannot be considered in an analysis of higher education as a filter in their host countries.

In order to compare the educational paths of the remaining individuals we had to decide on which degrees to count. In the U.S. and France higher education tends to be more modular than in Germany. Two or even more academic degrees may be awarded prior to the doctoral degree. In Germany, at the time relevant for our analysis, only a single academic degree was awarded after completion of the entire 4-6 year higher education program. Accounting for these differences, our category 'higher education degrees' in table 1 includes bachelor, master and first professional degrees for the U.S., Diplôme universitaire de technologie, License, Maîtrise and Diplôme d'ingénieur for France, and Diplom, Magister and Staatsexamen for Germany. The category 'doctoral degrees' refers to the U.S.-American Ph.D., the French Doctorate and the German Doktor. ${ }^{5}$

$4 \quad$ For further details see Franck and Opitz (2004).

5 A further differentiation of degrees into different subjects was not possible due to data limitations. In particular, the majority of French top managers only named their alma mater and did not further specify their subjects. 
Table 1: Educational paths of top managers

\begin{tabular}{|c|c|c|c|}
\hline & USA & Franc & German \\
\hline Higheeducatiodegre $^{a}$ & 97.8 & 97.3 & 95.1 \\
\hline Doctor degre ${ }^{b}$ & 5.5 & 4.1 & 58.5 \\
\hline Stateservic $^{c}$ & 1.1 & 44.6 & 2.4 \\
\hline $\mathrm{n}$ & 88 & 72 & 78 \\
\hline
\end{tabular}

In the U.S., 97.8 percent of the top managers in our sample hold a higher education degree according to this definition. For France and Germany the corresponding rates are 97.3 and 95.1 percent, respectively. These figures are quite similar. The following figures display remarkable differences, though: Whereas in the U.S. 5.6 percent of the $\mathrm{CEO}$ and in France 4.1 percent of the PDG in our sample hold a doctoral degree, in Germany no less than 58.5 percent of the VV do so. Only one American CEO and three German VV have spent part of their careers in the government administration. In France, on the other hand, 44.6 percent of the top managers in our sample have worked in the government administration prior to their actual employment.

In order to assess and compare the distribution of degrees among schools, another peculiarity of German higher education had to be accounted for. In Germany it is common practice among students to change schools once or even more times until earning their first official degree. This practice alone may indicate a uniform quality level in the university system, since otherwise such 'tourism' would collapse due to significant transaction costs. We considered only those schools on the educational path of a top manager that in fact awarded a final degree, since only a filter that has been successfully passed may serve as a valid signal.

In hierarchical higher education systems the interest of high potentials should be concentrated on a small group of top institutions, independently of how many institutions offer their services at the lower end of the reputational spectrum. High potentials choosing their alma mater in order to signal their talent should be observable right at the top of a hierarchical system. To get a first impression of a corresponding concentration of top managers at particular schools, we calculated the percentage of educated top managers who earned a degree at the school that was most frequently chosen by their peers. ${ }^{6}$ It turns out that 21.6 percent of the CEO with a higher educa-

6 There exists some variation in how countries count schools, and which schools they count. In France and Germany universities almost exclusively are single institutions that exist in only one place. For the U.S. we treated universities as single institutions and included their branch campuses and graduate schools. 
tion degree in our sample possess a degree from Harvard University, 30.6 percent of the educated PDG in our sample earned a degree from the École Polytechnique, and 9.0 percent of the educated German VV in our sample graduated from the LudwigMaximilians-Universität München (LMU). In the following steps we extended the group of schools by adding the school to our sample that finished next in every country as a 'producer' of degrees for top managers and asked how many top managers have earned a degree from at least one of these schools. The results for the ten schools that have been selected most often by the top managers in our sample are depicted in table 2.

\section{Table 2: Percentages of educated top managers holding a degree from the most frequented schools (cumulative)}

\begin{tabular}{llllllr}
\hline Number of schools & USA & & France & & Germany \\
1 & Harvard University & 21.6 & EP & 30.8 & LMU München & 9.0 \\
2 & Stanford University & 27.3 & ENA & 55.6 & RWTH Aachen & 16.7 \\
3 & Columbia University & 31.8 & HEC & 63.9 & Universität Bonn & 23.1 \\
4 & University of Chicago & 36.4 & IEP, Paris & 69.4 & Universität Freiburg & 29.5 \\
5 & MIT & 40.9 & ECP & 72.2 & Universität Münster & 35.9 \\
6 & Miami University & 45.5 & ESSEC & 75.0 & Universität Tübingen & 42.3 \\
7 & New York University & 50.0 & ENPC & 76.4 & TU Berlin & 46.2 \\
8 & University of Wisconsin & 54.5 & ENS & 77.8 & TH Darmstadt & 50.0 \\
9 & University of Pennsylvania & 58.0 & ENSM, Paris & 79.2 & Universität Saarbrücken & 53.8 \\
10 & Northwestern University & 61.4 & Univ. Paris XII & 80.6 & Universität Stuttgart & 57.7 \\
\hline
\end{tabular}

Of course, these figures may be distorted by different institutional sizes and sizes of student populations in the respective countries. In order to approximate a school's relative size we divided its number of graduates by the total number of graduates in its home country for the academic year 2000-2001. ${ }^{7}$ In that year only 0.39 percent of the U.S.-American higher education graduates obtained their degree at Harvard University, but 21.6 percent of the CEO in our sample did so. Compared to the whole population of graduates this particular school is 'over-represented' among top managers by a factor of 55.4. In France the École Polytechnique accounted for 0.14 percent of the French

Graduation figures for the different schools are head counts and were obtained from the schools' statistical yearbooks. The total numbers of graduates for the three countries were retrieved from the National Center for Education Statistics (2002, table 255), Ministère de l'Éducation Nationale (2003) and Statistisches Bundesamt (2003). This is a very rough procedure since present top managers graduated some time ago and school sizes as well as student populations have changed over time. We originally intended to use the graduation figures for the year 1975, when the average age of the top managers in our sample was 22.3. However, 1975 graduation figures did either not exist or were not available for all schools. 
graduates, but for 30.6 percent of the PDG in our sample. The corresponding 'elite factor' is 211.6.

If we compare the German figures with those for France and the U.S., the concentration of German top managers on a small number of schools is markedly less strong. The most frequented school (LMU) hosted about 2.4 percent of the German graduate population and 9.0 percent of the $\mathrm{VV}$ in our sample. This institution is thereby attended more often among top managers in our sample by a factor of 3.8. The figures for the ten most frequented schools are given in table $3 .^{8}$

Table 3: Elite factors for the most frequented schools

\begin{tabular}{lclrlr}
\hline & USA & & France & & Germany \\
Harvard University & 55.4 & EP & 211.6 & RWTH Aachen & 6.7 \\
MIT & 28.1 & ENA & 127.0 & Universität Freiburg & 6.2 \\
Stanford University & 27.2 & IEP, Paris & 108.4 & TH Darmstadt & 5.8 \\
University of Chicago & 22.5 & HEC & 53.3 & Universität Tübingen & 5.1 \\
Miami University & 18.7 & ENSM, Paris & 38.7 & Universität Stuttgart & 4.7 \\
Northwestern University & 12.8 & ENS & 35.3 & Universität Saarbrücken & 4.5 \\
Columbia University & 12.6 & ECP & 30.8 & Universität Bonn & 4.2 \\
University of Pennsylvania & 10.4 & ENPC & 30.5 & LMU München & 3.8 \\
University of Wisconsin & 7.5 & SUPELEC & 28.7 & Universität Münster & 3.8 \\
New York University & 7.5 & Univ. Paris XII & 1.9 & TU Berlin & 3.3 \\
\hline
\end{tabular}

Note: Elite factors are calculated by dividing the percentages of top managers holding a degree from these schools by the percentage of graduates of these schools of the total graduate population in their country for the academic year 2000-2001.

The educational choices of the top managers in our sample are consistent with our expectations. In particular we find:

- An outstanding importance of the doctoral degree for German top managers,

- a large fraction of French top managers that has spent part of their career within the state administration, and

- a strong preference of U.S.-American and French top managers for a few top and elite schools, respectively.

Finally, we look at whether the distinction between Fachbochschulen and Universitäten plays a role in the educational paths of German VV. 7.7 percent of the educated German top managers hold a degree from a Fachbochschule as their highest degree. This small ratio cannot be explained by enrolment figures alone. In the year 1975 Fachbochschulen accounted for 29.6 percent of the degrees awarded (Hochschul-

8 Since these 'elite factors' take into account different school sizes, a larger size for a particular school results in a smaller factor, when the number of top managers holding a degree from a particular school is constant. In consequence, the LMU only ranks on the 8th place, although the fraction of VV with a degree from this school was highest in our sample. 
Informations-System GmbH 2002: 221). German top managers obviously preferred Universitäten over Fachbochschulen. Signaling rents are one possible explanation for this choice.

\section{The future direction of the German doctorate as a signal for managerial talent}

\subsection{Reforms in doctoral education}

In recent years, the German chair-based model of doctoral education and training has been increasingly come under debate. The German Science Council (Wissenschaftsrat) supports plans of the German Research Foundation (Deutsche Forschungsgemeinschaft) to dramatically increase the number of so called 'Graduiertenkollegs' throughout the German university sector (Ruschkowski 2002, Berning/Falk 2005). ${ }^{9}$ Moreover, some German states (Bundesländer) have started to finance 'Graduiertenzirkel' at selected institutions and a number of universities have embarked on similar models of doctoral education by themselves. Finally, increasing efforts are currently made to harmonize doctoral education within the European Union, which may also limit the prospects of the traditional German chair-based model of doctoral education (Reichert/Tauch 2003, Kehm 2006). ${ }^{10}$

Graduiertenkollegs and similar concepts duplicate the practice of doctoral education at U.S. research universities (Kupfer/Moes 2003, Nerad 2002). At these institutions doctoral education is a highly structured third part of university studies following a predefined sequence of obligatory course work, research training and writing of the doctoral thesis. Application and selection procedures for new candidates are transparent and follow explicit rules. Coaching and teaching responsibilities in doctoral education are shared among the professors within a department. In general doctoral students are financed through grants, a fact which makes a substantial difference to the current employee status of German chair assistants.

From an academic point of view, which focuses on producing the next generation of successful researchers, the traditional chair-based model of doctoral education and training displays well-known shortcomings when compared with the structured programs as described above. The personalized relationship between professors and their assistants entails limitations for young academics who want to adopt independent and individual research foci. In order to preserve the goodwill of their supervisors, assistants have to serve the professor's interest by providing research support and assist in

9 Introduced in 1989, the Graduiertenkollegs form a system of graduate schools offering structured programs in doctoral education around special themes. Supported and financed by the DFG they are temporary in nature with a maximum duration of nine years. In the year 2004, about seven percent of all doctoral theses were written within such a research training group (DFG 2004). Although the Graduiertenkollegs have not replaced the traditional doctoral pattern, their introduction in 1989 marks the beginning of a formal alternative (Huisman/deWeert/Bartelse 2002).

10 In the U.S., on the other hand, contemporary doctoral education is not undisputed (e.g. Nerad 2002). Central criticism, though, addresses the content and objective and not the organization of doctoral education itself. 
various other projects. However, in order to gain visibility and recognition in the scientific community, which is important for future academic appointments, they need to undertake original research, which may differ or even contradict the work of their professor. Furthermore, candidates carry out a number of tasks that are only remotely related to their research projects. Administrative and teaching duties as well as contract work reduce the time candidates are able to spend on their own research. Moreover, the degree and quality of mentoring and coaching activities vary with the willingness, elaborateness and dedication of the supervisor.

Formal doctoral programs reduce the power and discretion of individual professors, promote the emergence of general standards in doctoral education and allow doctoral students to devote more time to their own research. Thus the envisaged reforms in German doctoral education are expected to increase research output and quality (Thaller 2006; Kehm 2005).

\subsection{The price of research orientation}

As we have argued above, German professors' incentives to engage in a careful selection of the most productive individuals and to further invest in their human capital crucially depend on the institutionalized and largely unrestricted access to their assistants' work power. Remember that all professors, those oriented towards research and those oriented towards consulting and project work, currently have these incentives because they all individually profit from talent. The candidates, on the other hand, gain professional experience, which is valuable for positions outside academia.

In this context the introduction of formal doctoral programs has the obvious effect to limit the access of professors to the working capacity of the new generation of doctoral students. These students do not contribute to the utility of the individual professor in a comparable way as the traditional chair assistants did. Why then should the individual professor continue to invest in the selection and monitoring of these students? And why should employers continue to assume that graduates with a doctoral degree are better suited for a management career if they know that professors do not profit anymore from economizing on their insider information on talent?

There are two relevant objections to this line of argument. First, it presupposes that the German higher education system remains an egalitarian bureaucracy, where the quality of doctoral education depends solely on the incentives of professors to maximize their own reputation. In contrast to the German case, in hierarchical education markets the individual well-being of faculty members is strongly connected to the success of their school. To the extent that doctoral programs contribute to this success, professors profit from investing time and energy in these programs, even without having individual access to the working power of doctoral candidates. If the German system of higher education would 'americanize' and transform into a hierarchical market in the long run, incentive mechanisms tied to the success of the school would automatically evolve. However, in this scenario the demand for doctorates as career accelerators would fade away anyway. In a hierarchical market high potentials have the option to signal their talent by graduating from a few top schools.

Second, one could argue that the scientific community has developed quite universal screening and monitoring procedures through the system of refereed publica- 
tions and conferences. ${ }^{11}$ By using the evaluation procedures of the scientific community even in a German department, where professors have only limited incentives to invest in the department's reputation, a 'good' formal doctoral program may be implemented without requiring too much professorial effort. Doctoral students basically are 'selected', 'coached' and 'monitored' by the scientific community if they are required to submit and present their papers at conferences and publish in refereed journals before they may defend their thesis. Moreover, to the extent that the department rules allow for co-authored papers in doctoral education, the logic of individual reputation management is at least partially back in the game. In this case research-oriented professors may have incentives to coach doctoral students because they individually profit from joint publications. But even if this combination of 'external' and 'specific internal' monitoring works well, it is restricted to the evaluation of research by its very nature.

Formal doctoral programs therefore are likely to produce a different kind of candidate. A doctoral degree earned in a 'good' formal doctoral program proves that the candidate has superior research abilities in a specific area of science. However, this is not what the majority of the candidates that embarked on the traditional German doctorate had in mind. They intended to produce a signal for superior talent by earning the doctoral degree that would enable them to accelerate their career outside academia. ${ }^{12}$

Concerning the employment of doctoral degree-holders outside academia, positions vary by the degree to which research is actually performed. Whereas doctoral degree-holders in the natural sciences or engineering tend to work in a more researchrelated environment, candidates with an economic or business studies background tend to embark on a management career and occupy professional and semiprofessional leadership positions. The current system of doctoral education and training is suited to address these labor market differences. In the natural sciences and engineering, assistant posts are relatively numerous because external funds are more affluent. Doctoral candidates in these fields usually conduct their research in a team context and participate in a research group at a university laboratory or an institute. These groups provide a more structured and focused research environment. In addition to the individual relationship with a professor, a larger group of researchers provides the doctoral candidates with the opportunity to interact more frequently and get support from their peers. Finally, it is common practice to organize doctoral colloquia in order to give the candidates the opportunity to present and discuss their work.

11 Frey (2004) gives a rather skeptical assessment of the current system of refereed publications.

12 According to a study on doctoral candidates in Bavaria conducted in 2003/2004, 70 percent of the candidates in the fields of business and economics planned a non-researchrelated private business career. The fraction of doctoral degree-holders that intends to continue an academic career varies considerably by discipline, but still, the vast majority of new doctors across all fields leaves the area of higher education (Berning/Falk 2006: 40). These patterns hold for Germany as a whole and seem to be quite stable over time (Enders/Teichler 1994). 


\subsection{Future signaling options for high potentials}

Concerning higher education politics in Germany, there are clear signs that state governments are willing to give institutions of higher education more flexibility in many aspects, including the selection of student-input, the design of new curricula and the internal allocation of their funds. However, in which direction German higher education will move in the long run is not yet clear.

Some Bundesländer have recently started to allocate fractions of their funds according to indicator-based schemes (Leszcensky 2004) and since 2006 the federal government has been promoting excellence in research by conducting a nationwide contest, the so called "initiative for excellence" (Exžellenæinitiative). Successful institutions receive significant additional financial resources over a five-year period (BMBF 2006). If such quality-based funding formulas would be consequently applied over longer periods of time and universities had to compete for public and private funds, German higher education could gradually move towards a hierarchically segmented market. In this scenario, high potentials without clear ambitions in science will stay away from doctoral education. Instead, they will select themselves into to the few high class institutions at the top of the system and graduate there in order to signal their talent.

Other German Länder plan to endow selected institutions with outstanding financial resources in order to establish a segment of elite education by fiat. If such a bureaucratic creation of elite schools would work, high potentials with a business career in mind would concentrate at these few predefined elite institutions. However, the creation of elite schools by fiat presupposes more than just a superior financial endowment. As the French case shows, a successful validation of predefined quality differences goes hand in hand with a corresponding state employment policy. This requirement, though, has received little attention in the scientific as well as the political discussion so far.

In a third scenario, elite education in the German public higher education sector will not take place, either because the remaining state regulation prevents a market driven hierarchization or because state authorities do not engage in a consequent implementation and validation of an elite segment. In this scenario, formal programs in doctoral education have two effects for high potentials heading for a management career: First, they devaluate the doctorate for them by changing its signaling content. Instead of certifying a more general form of human capital, the doctorate proves that the candidate has a specialized scientific education. Second, the investment in this specialized scientific education may raise the costs of doctoral education for the future managers. Although formal doctoral programs are likely to meet the demand of high potentials to a lesser degree, some of them may still take part. ${ }^{13}$ Others will look for feasible alternatives and migrate into the hierarchically differentiated systems of higher

13 Therefore, multiple paths to the doctoral degree which complement formal programs and include traditional chair assistants, junior positions at research institutes, universityindustry co-operations and self-financed external doctorates are especially valuable in this third scenario. Pluralism in doctoral education which is proposed by higher education experts and the majority of German university professors would allow for a self-selection of candidates and account for their differing educational needs (Berning/Falk 2006: 182). 
education abroad ${ }^{14}$ or will be attracted by private schools. With an increased number of highly talented applicants these private institutions may augment their outputquality by being more selective, gain size or increase in number. The prosperity of private management schools in Germany's higher education is clearly linked to the signaling opportunities given to high potentials in the public university sector.

\section{References}

Arrow, K. (1973): Higher Education as a Filter. In: Journal of Public Economics, 2: 193-216.

Astin, A.W. (1993): What Matters in College? Four Critical Years Revisited. Jossey-Bass.

Baldauf, B. (1998): Doctoral Education and Research Training: Towards a More Structured and Efficient Approach? In: European Journal of Education, 33: 161-182.

Berning, E./Falk, S. (2005): Das Promotionswesen im Umbruch. In: Beiträge zur Hochschulforschung, 27: 48-72.

Berning, E./Falk, S. (2006): Promovieren an den Universitäten in Bayern. München: Bayerisches Staatsinstitut für Hochschulforschung und Hochschulplanung.

BMBF (Federal Ministry of Education and Research) (2006): Initiative for Excellence: http://www.bmbf.de/en/1321.php, Berlin.

Chevaillier, T. (2001): French Academics: Between the Profession and the Civil Service. In: Higher Education, 41: 49-75.

Chevaillier, T. (1998): Moving Away from Central Planning: Using Contracts to Steer Higher Education in France. In: European Journal of Education, 33: 65-76.

Cohn, E./Kiker, B.F./Mendes de Oliveira, M. (1987): Further Evidence on the Screening Hypothesis. In: Economics Letters, 25: 289-294.

Deutsche Forschungsgemeinschaft (DFG) (2004): Entwicklung und Stand des Programms "Graduiertenkollegs” - Erhebung. http://www.dfg.de/forschungsfoerderung/koordinierte_programme/ graduiertenkollegs/download/erhebung2004.pdf. Bonn 2004.

Enders, J./Teichler, U. (1994): Doctoral Staff in German Higher Education: Selected Findings from the German Survey on the Academic Profession. In: Higher Education Policy, 7: 31-36.

Enders, J./Teichler, U. (1996): The Academic Profession in Germany. In: Altbach, P.G. (ed.): The International Academic Profession: Portraits of Fourteen Countries. San Francisco: Jossey-Bass: 439-492.

Enders, J./Bornmann, L. (2001): Karriere mit Doktortitel? - Ausbildung, Berufsverlauf und Berufserfolg von Promovierten. Frankfurt am Main: Campus.

Franck, E./Opitz, C. (2004): Zur Filterleistung von Hochschulsystemen - Bildungswege von Topmanagern in den USA, Frankreich und Deutschland. In: Schmalenbachs Zeitschrift für betriebswirtschaftliche Forschung, 56: 75-87.

Franck, E./Opitz, C. (2006): Incentive structures for professors in Germany and the United States: Implications for cross-national borrowing in higher education reform. In: Comparative Education Review, 50: 651-671.

Frank, R.H./Cook, P.J. (1995): The Winner-take-all Society. New York: Free Press.

Frey, B. (2004): Publishing as Prostitution? - Choosing Between One's Own Ideas and Academic Success. In: Public Choice, 166: 205-223.

Geiger, R.L. (2002): Differentiation, Hierarchy, and Diversity: An Overview of Higher Education in the United States. In: McC. Adam, R. (ed.): Trends in American and German Higher Education. Cambridge, MA: American Academy of Arts and Sciences: 19-32.

14 By introducing bachelor and master degrees throughout German higher education, the Bologna reform has dramatically increased the attractiveness of this latter option. High potentials pursue their bachelor degree in Germany and choose a prestigious foreign institution for their master study. Compared to the past situation in which German students had to obtain a diploma degree first before entering an international program, the new regime allows for a significant reduction of the total amount of time spent for their educational career. Bologna has put German universities under increased international competition for the most talented students, especially on the graduate level. 
Groot, W./Oosterbeek, H. (1994): Earnings Effects of Different Components of Human Capital vs. Screening. In: Review of Economics and Statistic, 76: 317-321.

Grubb, W.N. (1993): Further Tests of Screening on Education and Observed Ability. In: Economics of Education Review, 1: 315-337.

Hartmann, M. (2000): Class-specific Habitus and the Social Reproduction of the Business Elite in Germany and France. In: Sociological Review, 48: 241-261.

Hochschul-Informations-System GmbH (2002). In: HIS-Ergebnisspiegel 2002. Hannover.

Huisman, J. (2003): Higher Education in Germany. Enschede: CHEPS.

Huisman, J./de Weert, E./Bartelse, J. (2002): Academic Careers from a European Perspective. In: Journal of Higher Education, 73: 141-160.

Kehm, B. (2005): Developing Doctoral Degrees and Qualifications in Europe. Good Practices and Issues of Concern. In: Beiträge zur Hochschulforschung, 27: 10-33.

Kehm, B. (2006): Doctoral Education in Germany within the European Framework. In: Gorzka, G./Lanzendorf, U. (eds.): Europeanising Doctoral Studies. Kassel: Kassel University Press: 51-70.

Kupfer, A./Moes, J. (2003): Promovieren in Europa. Darmstadt: Spitzerdruck.

Leffers, J. (2003): Die Favoriten der Personalchefs. In: Der Spiegel 6: 12-18.

Leszcensky, M. (2004): Zukunftsweisendes Modell? Indikatorgesteuerte Mittelverteilung in elf Bundesländern. In: Forschung \& Lehre 9.

Ministère de l'Éducation Nationale et de la Culture (2003): Les Grands Chiffres de L'Éducation Nationale 2002/2003 - edition 2003. Paris.

Musselin, C. (1992): Steering higher education in France: 1981-1991. In: Higher Education in Europe, 17: $59-77$.

National Center For Education Statistics (2002): Digest of Education Statistics 2002, U.S. Department of Education.

Nerad, M. (2002): The PhD in the US: Criticisms, Facts and Remedies. In: Enders, J./De Weert, E. (eds.): Science, Training and Career - Changing Modes of Knowledge Production and Labor Markets. Enschede: CHEPS: 81-108.

Pascarella, E.T./Terenzini, P.T. (2005): How College Affects Students: A Third Decade of Research. San Francisco: Jossey-Bass.

Reichert, S./Tauch, C. (2003): Bologna Four Years After: Steps Toward Sustainable Reform of Higher Education in Europe. Brussels: European University Association.

Riley, J.G. (2001): Silver Signals: Twenty-five Years of Screening and Signaling. In: Journal of Economic Literature, 39: 432-478.

Rothschild, M./White, L.J. (1995): The Analytics of the Pricing of Higher Education and Other Services in Which the Customers are Inputs. In: Journal of Political Economy, 103: 573-586.

Ruschkowski, E. von (2002): Changes in PhD Training Proposed. http://nextwave.sciencemag.org/cgi/content/full/2002/11/26/13.

Schimank, U. (2001): Unsolved Problems and Inadequate Solutions: The Situation of Academic Staff in German Higher Education. In: Enders, J. (ed.): Academic Staff in Europe: Changing Contexts and Conditions. Westwood: Greenwood Press: 115-136.

Spence, M. (1973): Job Market Signaling. In: Quarterly Journal of Economics, 87: 355-374.

Statistisches Bundesamt (2003): Bestandene Prüfungen an Hochschulen 2000-2003. Wiesbaden: Bundesdruckerei.

Stiglitz, J.E. (1975): The Theory of 'Screening', Education, and the Distribution of Income. In: American Economic Review, 65: 283-300.

Thaller, N. (2006): Standards for Doctoral Programmes. Are there Organizational Determinants to successfully support Doctoral Candidates. In: Gorzka, G./Lanzendorf, U. (eds.): Europeanising Doctoral Studies. Kassel: Kassel University Press: 106-118.

Vaughan, M. (1981): The Grandes Écoles: Selection, Legitimation, Perpetuation. In: Howorth, J./Cerny, P.G. (eds.): Elites in France. London: Routledge: 93-103.

Weisbrod, B.A./Dominguez, N.D. (1986): Demand for Collective Goods in Private Non-Profit Markets. In: Journal of Public Economics, 30: 83-95.

Winston, G.C. (1999): Subsidies, Hierarchy and Peers: The Awkward Economics of Higher Education. In: Journal of Economic Perspectives, 13: 13-36. 